\title{
ANALISIS FINANCIAL INCLUSION TERHADAP PEMBERDAYAAN MASYARAKAT MISKIN DI MEDAN (STUDI KASUS PEMBIAYAAN MIKRO SS II DI BANK SUMUT SYARIAH)
}

\author{
Hairatunnisa Nasution \\ Mahasiswa Program Pascasarjana UIN Medan \\ nessanasoetion@gmail.com \\ Yasir Nasution \\ Dosen UIN Medan \\ Muhammad Yafiz \\ Dosen UIN Medan
}

j-EBIS

Jurnal Ekonomi dan Bisnis

Islam

Volume : 2

Nomor : 1

Halaman : 1-20

Langsa, April 2017

ISSN : 2502-1397

E-ISSN : 2540-8100

\section{Abstract}

This research aims to analyze the financial inclusion towards the empowerment of the poor in Medan through financing Sumut Sejahtera of the Bank Sumut Syariah. More specifically the research aims to know 1) the concept of financial inclusion that is implemented as a means of expanding access to financial services of banks and non-banks, 2) the application of the financial inclusion Bank Sumut Syariah. Bank Sumt Syariah have significant role in the economic development of the community through a variety of financing micro, Financing of the Sumut

Sejahtera. This financing facility has a lofty goal given to the community pre-prosperous society who have a business but not bankable feasibility so as to be worthy of being a customer of the bank, as well a improve people's lives and help governmentprograms in the framework of poverty reduction.The applicaton of financial inclusion on the financing Sumut Sejahtera of the Bank Sumut Syariah has been very clear benefits in the economic society prosper who enforce the interests for the public good. It is a basic principle in Islamic economic maqashid al-syariah. For financial inclusion theory maqashid al-syariah is one of the logical effort that must be applied as a consequence of the economic understanding of justice on one side and of religious on the other side.

Keywords: financial inclusion, empowerment, poverty

\section{PENDAHULUAN}

Peningkatan sektor jasa keuangan dalam kurun waktu 5 tahun terakhir mengalami ekspansi yang semakin meluas, hal ini mengindikasikan bahwa layanan keuangan menjadi satu hal terpenting dalam upaya perbaikan kesejahteraan bagi masyarakat menengah yang belum terbiasa dengan akses perbankan (unbanked). Pihak per- 
bankan semakin kompetitif dalam melakukan inovasi terhadap produk yang mereka tawarkan kepada para nasabah. Hal ini juga membuat akses serta kondisi wilayah dan geografis menjadi satu target perbankan agar lebih dekat kepada masyarakat, juga agar tidak mengesankan bahwa jasa keuangan hanya milik sekelompok orang di daerah perkotaan saja. Masyarakat memiliki hambatan dalam mengakses lembaga keuangan. Tingginya unbankable people disebabkan karena garis kemiskinan antar provinsi, rendahnya pembiayaan UMKM, suku bunga kredit mikro tinggi, asymmetric information, kemampuan manajemen UMKM kurang memadai, monopoli bank pada sektor mikro, dan terbatasnya saluran distribusi jasa keuangan. Inilah yang menjadi alasan urgennya penerapan Financial Inclusion.

Menurut Otoritas Jasa Keuangan, keuangan inklusif adalah segala upaya yang bertujuan untuk meniadakan segala bentuk hambatan yang bersifat harga maupun non-harga terhadap akses masyarakat dalam memanfaatkan layanan jasa keuangan sehingga dapat memberikan manfaat yang signifikan terhadap peningkatan taraf hidup masyarakat terutama untuk daerah dengan wilayah dan kondisi geografis yang sulit di jangkau atau daerah perbatasan. Dengan kontribusi seluruh masyarakat dalam industri keuangan, semakin banyak yang menabung, meminjam untuk modal usaha, berarti semakin dekat inklusi keuangan tercapai.(Abdul Rasyid, 2016)Bank Indonesia meluncurkan program National Strategy forFinancial Inclusion (NSFI) sebagai upaya untuk memperluas akses masyarakat terhadap jasa keuangan. Selama ini, 32\% atau 76 juta penduduk sama sekali belum tersentuh jasa keuangan (financial exclusion). Selain itu, 60-70\% Usaha Mikro, Kecil, dan Menengah (UMKM) juga belum memiliki akses terhadap perbankan. Padahal hampir 53 juta masyarakat miskin yang bekerja di sektor UMKM memiliki potensi yang sangat besar untuk menurunkan pengganguran dan mengurangi kemiskinan. Implementasi Financial Inclusion di Indonesia sudah dilakukan dalam berbagai bentuk seperti pemberian Kredit Usaha Rakyat (KUR) dan pengembangan BMT (Baitul Mal wa al-tamwil). KUR adalah skema kredit usaha khusus bagi UMKM dan koperasi yang telah memenuhi standar kelayakan usaha namun tidak memiliki agunan sesuai dengan persyaratan yang ditetapkan oleh perbankan. Melalui program KUR pemerintah berupaya meningkatkan akses UMKM kepada kredit usaha dari perbankan dengan cara meningkatkan kapasitas perusahaan penjamin.

Kebijakan dibidang Keuangan Inklusif merupakan langkah tepat di dalam mengurangi tingkat kemiskinan di Indonesia.Implementasi Financial Inclusion di Indonesia sudah dilakukan dalam berbagai bentuk.Salah satunya lagi adalah Presiden Joko Widodo melalui Otoritas Jasa Keuangan (OJK) telah membentuk Tim Akses Percepatan Keuangan Daerah (TPKAD) seluruh Indonesia pada Tanggal 17 Januari 2016.TPAKD lahir dari kondisi di masyarakat yang membutuhkan akses keuangan untuk keperluan pribadi, keluarga maupun usaha. Oleh karena itu,TPAKD sebagai forum koordinasi antarin- 
stansi dan stakeholders diharapkan dapat meningkatkan dan mempercepat akses keuangan di daerah dalam rangka mendorong pertumbuhan ekonomi serta mewujudkan masyarakat yang lebih sejahtera ( Bapak Manihut Parlindungan Aritonan, staf pegawai OJK bagian edukasi bimbingan onsumen).Salah satu contoh yang sudah merealisasikan TPAKD adalah Provinsi Jawa Tengah yang telah menyiapkan serangkaian program kerja yang nantinya hasilnya diharapkan dapat dirasakan secara langsung oleh masyarakat. Program kerja yang telah disusun adalah 1) Fasilitasi Pembiayaan LJK ke sektor UMKM/rintisan usaha, 2) Implementasi Gerakan Budaya Menabung Bagi Pelajar, 3) Peningkatan Jumlah Agen Laku Pandai di daerah, dan 4) Asistensi UMKM masuk bursa.

Selain di Jawa Tengah ada juga di Provinsi Bali yang sudah menjalankan TPAKD. Adapun program kerja yang telah disusun adalah 1) Peningkatan ketahanan pangan melalui program asuransi usaha tani padi (AUTP) dan asuransi usaha ternak sapi (AUTS), 2) Akselerasi program pembangunan 100 desa wisata, 3) Penyaluran KUR bagi UMKM, dan 4) Program peningkatan literasi keuangan masyarakat.Sementara di Provinsi Sumatera Utara sudah dalam pembentukan pengurus dengan beberapa program (belum disahkan oleh Gubernur, masih dalam proses) yang nantinya akan direalisasikan pada awal Februari 2017 kedepan dengan beberapa pengurus. Kepala OJK Regional 5 Sumatera Utara Soekro Tratmono mengatakan pembentukan TPAKD Sumut sebenarnya telah merefleksikan 2 program pokok master plan sektor jasa keuangan yaitu jasa keuangan yang kontributif dan inklsif.Kontributif yakni dilaksanakan melalui program pengembangan produk dan layanan sektor jasa keuangan serta peningkatan literasi keuangan. Sedangkan inklusif dilaksanakan melalui pembangunan potensi ekonomi daerah dan penguatan akses keuangan dan penguatan perlindungan konsumen( Evalisa siregar 2017).

Perbankan syariah juga merupakan lembaga penting dalam mengimplementasi financial inclusion di Indonesia. Pada Desember 2013 saja Indonesia telah memiliki 11 Bank Umum Syariah (BUS), 23 Unit Usaha Syariah (UUS), dan 16 Bank Pembiayaan Rakyat Syariah (BPRS). Ini merupakan bukti konkrit bahwa perbankan syariah mampu bertahan dan tumbuh meskipun di tengah instabilitas ekonomi, seperti krisis 1998, 2008 dan krisis yang melanda Eropa 2011 silam. Perkembangan secara kuantitas ini sudah tersebar dari pusat hingga ke daerah sehingga bisa dijangkau oleh semua lapisan masyarakat. Keberadaan perbankan syariah sebagai salah satu bagian penting dari lembaga keuangan formal di negeri ini diharapkan mampu mengimplementasikan Financial Inclusion. 
Makin meluasnya jangkuan perbankan syariah menunjukkan peran perbankan syariah makin besar untuk pembangunan rakyat di negeri ini. Salah satunya Bank Sumut Syariah akan tampil sebagai garda terdepan terwujudnya Financial Inclusion. Bank Sumut Syariah ini memiliki kelebihan dibandingkan dengan lembaga perbankan syariah lainnya. Selain prinsip-prinsip syariah yang menjadi basis fundamentalnya, operasional Bank Sumut Syariah dilakukan dengan cara pendampingan kepada para anggotanya sehingga model pendekatan ini memunculkan sebuah tingkat kepercayaan yang sangat tinggi kepada para anggotanya. Hal ini yang menjadikan Bank Sumut Syariah akan semakin menjamur di masyarakat sebagai Financial Inclusion.

\section{METODE PENELITIAN}

Penelitian ini bertujuan untuk menganalisis financial inclusion terhadap pemberdayaan masyarakat miskin di medan dengan objek penelitiannya di Pembiayaan Sumut Sejahtera Bank Sumut Syariah.. Secara lebih khusus penelitian ini ingin mengetahui, 1) Konsep financial inclusion diimplementasikan menjadi sarana perluasan akses jasa keuangan bank dan non bank, 2) Bagaimana cara Bank Sumut Syariah menerapkan konsep financial inclusion terhadap masyarakat.

Sumber data yang digunakan dalam penelitian ini meliputi kepada sumber primer dan skunder.Metode yang digunakan dalam penelitian ini adalah menggunakan perpektif pendekatan kualitatif.Fokus penelitiannya adalah studi Financial Inclusion terhadap pemberdayaan masyarakat miskin di Medan dengan studi kasus Pembiayaan Sumut Sejahtera Bank Sumut Syariah dalam rangka mengentaskan dan memberdayakan kemiskinan.Pengumpulan data yang dilakukan dalam penelitian ini adalah wawancara dan observasi terhadap nasabah Bank Sumut Syariah.

\section{FINANCIAL INCLUSION}

\section{Pengertian Financial Inclusion}

Financial Inclusion didefinisikan sebagai upaya mengurangi segala bentuk hambatan yang bersifat harga maupun non harga, terhadap akses masyarakat dalam memanfaatkan layanan jasa keuangan(Halim Alimsyah,2016).Financial Inclusion merupakan sebagai bentuk strategi nasional Keuangan Inklusif yaitu hak setiap orang untuk memiliki akses dan layanan penuh dari lembaga keuangan secara tepat waktu, nyaman, informatif, dan tejangkau biayanya, dengan penghormatan penuh kepada harkat dan martabat.

Global Financial Development Report (2014) mendefenisikan Financial Inclusion sebagai The proportion of individuals and firms that use financial service has become a subject 
of considerable interest amn policy makers, researchers and other stakeholder, Financial Inclusion merupakan suatu keadaan dimana mayoritas individu dapat memanfaatkan jasa keuangan yang tersedia serta meminimalisir adanya kelompok individu yang belum sadar akan manfaat akses keuangan melalui akses yang telah tersedia tanpa biaya yang tinggi ( Melisa Salim, 2014).

Menurut Otoritas Jasa Keuangan, Keuangan Inklusi adalah segala hal upaya yang bertujuan untuk meniadakan segala bentuk hambatan yang bersifat harga maupun non-harga terhadap akses masyarakat dalam memanfaatkan layanan jasa keuangan sehingga dapat memberikan manfaat yang signifikan terhadapa peningkatan taraf hidup masyarakat terutama untuk daerah dengan wilayah dan kondisi geografis yang sulit dijangkau atau daerah perbatasan (Triana Fitriastuti, 2015: 40).

Kamalesh Shailesh C. Chakrobarty (2011) mengatakan Financial Inclusion mempromosikan penghematan dan mengembangkan budaya menabung, meningkatkan akses kredit, baik kewirausaahaan maupun konsumsi dan juga memungkinkan mekanisme pembayaran yang efisien, sehingga memperkuat basis sumber daya lembaga keuangan yang mampu memberikan manfaat ekonomi sebagai sumber daya dan tersedianya mekanisme pembayaran yang efisien dan alokatif. Dengan demikian, Financial Inclusion hari ini bukanlah merupakan pilihan, tetapi menjadi sebuah keharusan dan perbankan merupakan pendorong utama untuk implementasi Financial InclusionNovia Nengsih, 2015 : 223-224).

Untuk mewujudkan inklusif keuangan tentunya diperlukan sebuah lembaga keuangan yang langsung bersentuhan dengan masyarakat terutama kelas menengah ke bawah. Salah satu keuangan mikro berbasis syariah adalah Bank Sumut Syariah, selain prinsip-prinsip syariah yang menjadi basis fundamentalnya, operasional Bank Sumut Syariah dilakukan dengan cara pendampingan kepada para anggotanya sehingga model pendekatan ini memunculkan sebuah tingkat kepercayaan yang sangat tinggi kepada para anggotanya.Lembaga keuangan Bank Sumut Syariah mempunyai peran signifikan dalam pengembangan ekonomi masyarakat melalui berbagai pembiayaanya.Hal ini tidak terlepas dari kemudahannya akses oleh mayarakat daerah. Kegiatan Keuangan Inklusif diharapkan dapat mendukung stabilitas keuangan yang menjadi landasan pokok bagi pembangunan ekonomi yang kokoh. Dari sisi makro, kegiatan ini diharapkan dapat mendukung pertumbuhan ekonomi yang semakin inklusif dan berkelanjutan serta dapat memberi manfaat bagi kesejahteraan rakyat banyak (Farhan Maulani, 2016). 


\section{Visi dan Tujuan Financial Inclusion}

Visi nasional Financial Inclusiondirumuskan untuk mewujudkan sistem keuangan yang dapat diakses oleh seluruh lapisan masyarakat untuk mendorong pertumbuhan ekonomi, penanggulangan kemiskinan, pemerataan pendapatan dan terciptanya stabilitas sistem keuangan di Indonesia.

Tujuan Financial Inclusion tersebut dijabarkan dalam beberapa tujuan sebagai berikut:

a. Menjadikan strategi Keuangan Inklusif sebagai bagian dari strategi besar pembangunan ekonomi, penanggulangan kemiskinan, pemerataan pendapatan dan stabilitas sistem keuangan.

b. Menyediakan jasa dan produk keuangan yang sesuai dengan kebutuhan masyarakat.

c. Meningkatkan pengetahuan masyarakat mangenai layanan keuangan.

d. Meningkatkan akses masyarakat ke layanan keuangan.

e. Memperkuat sinergi antara Bank, lembaga keuangaan mikro, dan lembaga keuangan non Bank.

f. Mengoptimalkan peran teknologi informasi dan komunikasi (TIK) untuk memperluas cakupan layanan keuangan.

\section{Manfaat Financial Inclusion}

Adapun manfaat dari Keuangan Inklusif yang dapat dinikmati oleh masyarakat, regulator, pemerintah dan pihak swasta, antara lain sebagai berikut:

- Meningkatkan efisiensi ekonomi.

- Mendukung stabilitas sistem keuangan.

- Mengurangi shadow Banking atau irresponsible finance.

- Mendukung pendalaman pasar keuangan.

- Memberikan potensi pasar baru bagi perBankan.

- Mendukung peningkatan Human Development Index (HDI) Indonesia.

- Berkontribusi positif terhadap pertumbuhan ekonomi lokal dan nasional 
yang berkelanjutan.

- Mengurangi kesenjangan (inequality) dan rigiditas low income trap, sehingga dapat meningkatkan kesejahteraan masyarakat yang pada akhirnya berujung pada penurunan tingkat kemiskinan.

\section{Implementasi Strategi Nasional Financial Inclusion}

Berbagai insisiatif telah dilakukan oleh Kementrian/instansi terkait dalam rangka implementasi strategi nasional Keuangan Inklusif . Hal ini menunjukkan komitmen dari berbagai Kementrian/instansi terkait untuk secara aktif berupaya mengimplementasikan rencana-rencana masa depan serta program-program yang berkaitan dengan strategi nasional Keuangan Inklusif diantaranya:

1. Peran Keuangan Inklusif sangat penting untuk pengentasan kemiskinan, pertumbuhan ekonomi, dan stabilitas keuangan.

2. Penerapan SNKI memerlukan kerjasama dan koordinasi yang baik dari berbagai pemangku kepentingan, baik dari lembaga pemerintah, swasta, dan masyarakat sendiri.

3. Proses implementasi dan pemantauan strategi national Keuangan Inklusif akan terbagi dalam:
a. Inventarisasi ketersediaan data dan diagnose kondisi saat ini
b. Penetu target dan tujuan yang tercantum daam indikator kinerja utama
c. Peran sektor publik dan swasta
d. Pemantauan kemajuan kegiatan

4. Kepemimpinan diperlukan untuk mengkoordinasikan tindakan dan mempertahankan dorongan serta momentum untuk reformasi( Badan kebijakan Fiskal Kementerian Keuangan Republik Indonesia, 2013 : 33).

\section{PEMBERDAYAAN}

Istilah pemberdayaan berasal dari kata daya, kata daya dalam kamus besar bahasa Indonesia berarti kekuatan dan kemampuan. Sementara pemberdayaan merupakan cara, proses, upaya untuk menjadikan pihak lain memiliki daya atau kekuatan.Kamus Besar Bahasa Indonesia, 2003: 241-242) Pemberdayaan merupakan sebagai upaya penyediaan sumber daya, kesempatan, pengetahuan dan keterampilan bagi mas- 
yarakat untuk meningkatkan kapasitas mereka, sehingga dapat menemukan masa depannya yang lebih baik( Jim Ife, 2005:182).

Pemberdayaan pada intinya membahas bagaimana individu, kelompok, ataupun komunitas berusaha mengontrol kehidupan mereka sendiri dengan keinginan mereka. Pemberdayaan juga dapat diartikan sebagai suatu proses yang relatif terus berjalan untuk meningkatkan kepada perubahan. Amrullah ahmad mengatakan bahwa "Pengembangan Masyarakat Islam adalah sistem tindakan nyata yang menawarkan alternative model pemecahan masalah umat dalam bidang sosial, ekonomi dan lingkungan dalam perpektif Islam( M Amrullah Ahmad, 1999: 9).

Dalam Ensiklopedia Indonesia, Daya adalah kemampuan melakukan sesuatu atau kemampuan untuk bertindak. Dalam konteks kaum duafa pemberdayaan adalah membantu pihak yang diberdayakan untuk memperoleh daya mengambil keputusan dan menentukan tindakan yang akan dilakukan tentang diri mereka, termasuk mengurangi efek hantaman pribadi maupun sosial, melalui peningkatan kemampuan dan rasa percaya diri untuk menggunakan daya yang dimiliki ( Isbandi Rukminto, 2002:162). Pemberdayaan juga ada yang memahami sebagai upaya untuk membangun daya yang dimiliki kaum duafa dengan mendorong, memberikan motivasi dan meningkatkan kesadaran tentang potensi yang dimilikinya serta berupaya untuk mengembangkannya( Gunawan Sumohadiningrat,1997: 165).

Dari kesimpulan diatas, maka disimpulkan bahwa yang dimaksud pemberdayaan adalah sebuah gerakan penguatan sosial agar masyarakat tadinya lemah, baik dalam bidang sosial, ekonomi serta politik, diberdayakan sehingga membangkitkan kesadaran masyarakat tersebut dan meningkatkan potensi yang mereka milki dan guna membangun serta menentukan tindakan tertentu yang dapat menjamin keberhasilan hakiki dalam bentuk kemandirian.

\section{KEMISKINAN}

\section{Pengertian dari Kemiskinan}

Pengertian Kemiskinan adalahSecara harfiah kamus besar Bahasa Indonesia, miskin itu berarti tidak berharta benda.Miskin juga berarti tidak mampu mengimbangi tingkat kebutuhan hidup standard dan tingkat penghasilan dan ekonominya rendah. Secara singkat kemiskinan dapat didefenisikan sebagai suatu standar tingkat hidup yang rendah yaitu adanya kekurangan materi pada sejumlah atau segolongan orang dibandingkan dengan standard kehidupan yang berlaku dalam masyarakat yang bersangkutan. 
Menurut Mardimin, Kemiskinan itu yaitu: ( Mardimin Yohanes,1996:20)

1. Secara kualitatif, definisi kemiskinan adalah suatu kondisi yang didalamnya hidup manusia tidak layak sebagai manusia, dan

2. Secara kuantitatif, kemiskinan adalah suatu keadaan dimana hidup manusia serba kekurangan, atau dengan bahasa yang tidak lazim "tidak berharta benda"

Ragam penjelasan tentang kemiskinan atau persisnya tentang mengapa terjadi kemiskinan. Menurut Bradshaw dalam bukunya Antonio Pradjoto, ada lima penjelasan mengapa kemiskinan timbul, yaitu:( Antonio,2008: 14)

a. Kelemahan-kelemahan individual

b. Sistem budaya yang mendukung subkultur kemiskinan

c. Distorsi-distorsi ekonomi-politik atau diskriminasi sosial-ekonomi

d. Kesenjangan kewilayahan

e. Asal-usul lingkungan yang bersifat kumulatif

Berbeda dengan Fitzpatrick, ia menuliskan bahwa penjelasan tentang sebab musabab kemiskinan tidak bisa lepas dari konstentasi konseptual kanan-kiri dalam ilmu sosial. Lebih jauh Fitzpatrick menulis bahwa 5 tipe penjelasan mengenai sebab-sebab kemiskinan yaitu: ( Mardimin Yohanes,1996:20)

a. Miskin karena gen kemiskinan

b. Miskin karena lingkungan yang memiskinkan (cycle of deprivation)

c. Miskin karena kegagalan-kegagalan kebijakan

d. Miskin karena rintangan-rintangan struktural (structural constraints) yaitu adanya kekuatan di luar dirinya yang menghalangi si miskin untuk bergerak dan berubah menjadi tidak miskin

e. Miskin sebagai fungsi dari kapitalisme karena tenaga kerja cadangan diperlukan dalam kapitalisme.

Kemiskinan merupakan masalah nasional yang tidak hanya dapat diselesaikan oleh pemerintah tetapi menjadi tanggungjawab bersama baik pemerintah, swasta, lembaga profesi, perguruan tinggi maupun masyarakat itu sendiri. Permasalahan ke- 
miskinan tersebut jika tidak diwaspadai serta dilakukan upaya dan langkah konkrit untuk menanggulanginya Akan membawa akibat yang buruk seperti menurunkan kualitas sumber daya manusia, timbulnya kecemburuan sosial, pengangguran, kerentanan, kriminalitas dan berbagai dampak negatif lainnya.

\section{Faktor Penyebab Kemiskinan}

Para ilmuwan sosial membagi dua jenis penyebab kemiskinan: (Michael Sarraden dkk, 2006:47)

a. Kemiskinan terjadi karena faktor perilaku individu, bahwa sikap individu yang tidak produktif telah mengakibatkan lahirnya kemiskinan

b. Kemiskinan terjadi karena struktur sosial, keadaan masyarakat dan tatanannya yang tidak benar melahirkan kemiskinan. Dalam hal ini keadaan masyarakat yang miskin menjadikan individu-individu anggota masyarakatnya tidak produktif

\section{Pandangan Islam Tentang Kemiskinan}

tPara ulama berbeda pendapat tentang derajat kemiskinan apabila dibandingkan dengan kekayaan.Paling tidak, ada dua kelompok.Kelompok pertama berpendapat bahwa kemiskinan dan kefakiran lebih baik daripada kekayaan.Diantara argumen yang diajukan adalah beberapa ayat Al-Quran yang memuji orang-orang yang fakir, diantaranya adalah firman Allah dalam surat Al-Baqarah, 2:273

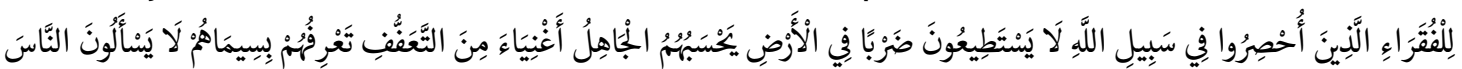

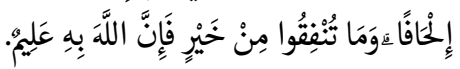

Artinya: "(Berinfaqlah) kepada orang-orang fakir yang terikat (oleh jihad) di jalan Allah; mereka tidak dapat (berusaha) di bumi; orang yang tidak tahu menyangka mereka orang Kaya Karena memelihara diri dari minta-minta. kamu kenal mereka dengan melihat sifat-sifatnya, mereka tidak meminta kepada orang secara mendesak. dan apa saja harta yang baik yang kamu nafkahkan (di jalan Allah), Maka Sesungguhnya Allah Maha Mengetahui."

Belum lagi hadis-hadis Nabi sallallahu'alaihi wa sallam cukup banyak yang pada intinya memuji orang-orang yang miskin. Diantara yang terkenal adalah sebuah doa yang dipanjatkan oleh Rasulullah sallallahu'alaihi wa sallam yang berbunyi :"Ya tuhan, hidupkanlah aku dalam kemiskinan dan matikanlah dalam kemiskinan dan bangkitkanlah dari kematian bersama orang-orang yang miskin". Kelompok kedua menganggap bahwa kekayaan jelas lebih utama daripada kemiskinan.Di antara argument yang disampaikan adalah bahwa kekayaan itu adalah salah satu sifat Tuhan, sedangkan kemi- 
skinan tidak dapat dinisbatkan kepadaNya.

\section{PENERAPAN FINANCIAL INCLUSION PT BANK SUMUT SYARIAH}

Penerapan Financial Inclusiondalam menangani kemiskinan melaluiPembiayaan Mikro Sumut Sejahtera Ilyang ada di Bank Sumut Syariah. Fasilitas pembiayaan ini memiliki tujuanmulia diberikan kepadamasyarakat pra-sejahterayang memilikiusahamikrountuk:

- Meningkatkan peran masyarakat dalam menopang ekonomi keluarga dengan sistem kelompok guna memperbaiki taraf hidup keluarga pra-sejahtera atau berpenghasilan rendah menuju ke taraf sejahtera yang lebih baik,

- Membina pengusaha mikro yang memiliki kelayakan usaha tetapi belum Bankable sehingga menjadi layak menjadi nasabah Bank,

- Serta mewujudkan visi dan misi Bank Sumut Syariah khususnya dalam rangka meningkatkan taraf hidup rakyat dan membantu program Pemerintah dalam rangka pengentasan kemiskinan.

Adapun persyaratan umum Pembiayaan Sumut Sejahtera II ini :

- $\quad$ Foto copy KTP pemohon dan suami/isteri (jika ada)

- Foto copy Kartu Keluarga

- Fotocopy Akta Nikah/cerai/pisah harta (jika ada)

- Faktur bon penjualan

- Pembiayaan bertahap dengan Plafond Rp 5.000.000 - Rp.50.000.000

Makin meluasnya jangkuan perbankan syariah menunjukkan peran perbankan syariah makin besar untuk pembangunan rakyat di negeri ini. Salah satunya Bank Sumut Syariah akan tampil sebagai garda terdepan terwujudnya Financial Inclusion. Bank Sumut Syariah ini memiliki kelebihan dibandingkan dengan lembaga perbankan syariah lainnya. Selain prinsip-prinsip syariah yang menjadi basis fundamentalnya, operasional Bank Sumut Syariah dilakukan dengan cara pendampingan kepada para anggotanya sehingga model pendekatan ini memunculkan sebuah tingkat kepercayaan yang sangat tinggi kepada para anggotanya. Hal ini yang menjadikan Bank Sumut Syariah akan semakin menjamur di masyarakat sebagai Financial Inclusion. Bank Sumut Syariah mempunyai peran signifikan dalam pengembangan ekonomi masyarakat melalui berbagai pembiayaan mikronya yaitu Pembiayaan Mikro Sumut Sejahtera II. Hal ini tidak terlepas dari kemudahannya diakses oleh masyarakat.Fasilitas kredit ini memili- 
ki tujuan mulia diberikan kepada masyarakat pra-sejahtera yang memiliki usaha mikro guna memperbaiki taraf hidup keluarga pra-sejahtera atau berpenghasilan rendah menuju ke taraf sejahtera yang lebih baik, membina pengusaha mikro yang memiliki kelayakan usaha tetapi belum bankable sehingga menjadi layak menjadi nasabah bank, serta meningkatkan taraf hidup rakyat dan membantu program Pemerintah dalam rangka pengentasan kemiskinan.

Penerapan financial inclusion Bank Sumut Syariah diharapkan semakin meningkat agar anggota atau nasabah lebih mudah untuk bertransaksi baik menabung maupun melakukan pembiayaan. Sebagian nasabah mengatakan jarak pasar dan kantor sangat dekat, jangkauan yang hemat baik hemat tenaga maupun hemat waktu. Selain itu Bank Sumut Syariah memberikan ksesejahteraan dengan berupa keuntungan dalam melakukan angsuran pembiyaan sumut sejahtera. Sistem pemasaran yang diterapkan Bank Sumut Syariah yaitu memberikan keamanan dan kenyamanan bagi anggota karena anggota tidak perlu datang ke kantor untuk melakukan transaksi secara langsung. Melainkan marketing menggunakan sistem jemput bola atau pick-up service, langsung mendatangi anggota. Kemudahan dalam mendapatkan pelayanan yang maksimal akan menumbuhkan sikap kepuasan terhadap pelayanan yang diberikan oleh Bank Sumut Syariah. Hal ini merupakan hubungan saling menguntungkan antara anggota dengan petugas marketing.

Sistem jemput bola pick-up service bukan hanya dilakukan untuk menambah jumlah anggota sehingga mampu meningkatkan pendapatan operasional suatu lembaga keuangan namun juga dilakukan untuk membuat anggota setia dengan memberikan pelayanan yang baik serta maksimal. Keloyalan petugas marketing menjadi ujung terwujudnya kesetiaan anggota. Karena ketika anggota merasa dihormati dan dihargai maka mereka akan memberikan perlakuan yang sama. Para Bankir Bank Sumut telah membuktikan bahwa pegawai Bank tidak harus berdiam diri di kantor menunggu nasabah mereka datang. Mereka berkeliling memberikan pembelajaran kepada para masyarakat di pedesaan, untuk bisa menjalankan usaha mereka dengan baik.Jadi bukan hanya sekedar memberikan pinjaman lantas membiarkan begitu saja.Mereka bekerja dengan melakukan pendekatan untuk memotivasi para nasabah mereka, sehingga nasabah tidak mempermasalahkan tambahan uang yang harus mereka bayarkan untuk pembagian hasil laba.Dan terbukti sangat sedikit sekali adanya kredit macet.Mereka dididik menjadi seorang wirausaha, yang bisa menghasilkan ouput produk/ jasa untuk dipasarkan di antara mereka. 


\section{ANALISIS FINANCIAL INCLUSION TERHADAP PEMBERDAYAAN MASYARAKAT MISKIN DI MEDAN}

Berdasarkan analisis yang ditemukan di dalam data laporan jumlah Pembiayaan Mikro Sumut Sejahtera II yang telah terdaftar di Bank Sumut Syariah Cabang Medan pada tahun 2013 - 2015 terlihat dalam tabel di bawah ini:

\begin{tabular}{|l|l|}
\hline Bulan & Jumlah \\
\hline Januari & 1 orang \\
\hline Februari & 1 orang \\
\hline Maret & 1 orang \\
\hline April & 1 orang \\
\hline Mei & 2 orang \\
\hline Juni & 1 orang \\
\hline Juli & 1 orang \\
\hline Agustus & 2 orang \\
\hline September & 1 orang \\
\hline Oktober & 2 orang \\
\hline Novemper & 3 orang \\
\hline Desember & 4 orang \\
\hline
\end{tabular}

Sumber: Data laporan dari Bank Sumut Syariah Pusat

Dari hasil jumlah laporan penggunaan produk Pembiayaan Mikro Sumut Sejahtera II menunjukkan terlihat mengalami perubahan jumlah kenaikan anggota tiap bulannya. Dari data diatas dapat dilihat pada laporan bulanan tahun 2015, laporan jumlah anggota pembiayaan menunjukkan perubahan yang baik. Meskipun laporan jumlah anggota sudah mampu menunjukkan hasil yang diharapkan, perlu diperhatikan juga keluhan yang disampaikan anggota. Karena dengan keluhan anggota bisa menjadi bahan evaluasi dalam meningkatkan keuangan inklusif yang lebih baik lagi. Dalam pengembangan keuangan inklusif tidak dipungkiri akan ditemui banyak kendala di sana sini. Hal tersebut yang mendasari perlunya penguatan regulasi dari penggunaan strategi yang efektif, karena implementasi yang menjadi faktor berikutnya yang akan menentukan dalam pelaksanaan suatu strategi secara efektif.

Dari pemaparan di atas, penulis menyimpulkan adanya beberapa aspek dari analisis financial inclusionyang ada pada Bank Sumut Syariah yaitu:

\section{Aspek Kemudahan Simpanan}

Adapun aspek kemudahan simpanan di Bank Sumut Syariah yaitu:

- Potongan bulanan yang sedikit 
- Mudah dijangkau

- Tidak ribet untuk membuka tabungan sekalipun dengan memakai KTP luar daerah

Minat penabung di bank Sumut Syariah Tahun 2013-2015 dapat dilihat pada tabel di bawah ini:

Tabel.1

\begin{tabular}{|l|l|l|l|l|}
\hline No & Jenis Tabungan & $\begin{array}{l}\text { Jumlah Nasabah } \\
\text { Tahun 2013 }\end{array}$ & $\begin{array}{l}\text { Jumlah Nasabah } \\
\text { Tahun 2014 }\end{array}$ & $\begin{array}{l}\text { Jumlah Nasabah } \\
\text { Tahun 2015 }\end{array}$ \\
\hline 1 & Deposito & 3.405 orang & 3514 orang & 3451 orang \\
\hline 2 & Giro & 113 orang & 177 orang & 246 orang \\
\hline 3 & Mudharabah & 43.791 orang & 49624 orang & 54487 orang \\
\hline 4 & Wadiah & 35.648 orang & 39106 orang & 43436 orang \\
\hline
\end{tabular}

Sumber: Data laporan dari Bank Sumut Syariah Pusat

Berdasarkan data yang diperoleh dari Bank Sumut Syariah Pusatditemukan bahwa minat menabung atau menyimpan di Bank Sumut Syariah ini sangat banyak (meningkat), dibuktikan dari laporan jumlah kepemilikan tabungan dalam kurun waktu terakhir semakin meningkat.

\section{Aspek Kemudahan Pinjaman}

Adapun aspek kemudahan simpanan di Bank Sumut Syariah dalam Pembiayaan Sumut Sejahtera II ini adalah:

- Persyaratan mudah

- Tidak adanya agunan dalam pinjaman

- Profit margin

- Gratis Asuransi Syariah

- Dapat mendambah modal usaha atau investasi usaha

- Pick up service angsuran dari marketing pembiayaannya

- Sistem bagi hasil

Pembiayaan Mikro Sumut Sejahtera II ini sangat banyak diminati oleh masyarakat, bukan hanya masyarakat yang beragama Islam saja yang melakukan pinjaman Pem- 
biayaan Mikro Sumut Sejahtera II, bahkan masyarakat yang non Islam juga ikut melakukan pinjaman ini karena kemudahannya dalam memperoleh pinjaman. Dari data perkembangan Pembiayaan Mikro Sumut Sejahtera II dalam kurun waktu Tahun 2015 dinyatakan berhasil karena data yang dilihat diatas semakin meningkat. Sehingga memancing calon anggota yang lain yang kemudian menjadi anggota untuk terus berinteraksi dan melakukan transaksi dengan Bank Sumut Syariah dalam jangka panjang.

\section{Aspek Kemudahan Aksesbilitas}

Berdasarkan evaluasi terdapat aspek kemudahan aksesbilitas di Bank Sumut Syariah, dibuktikan dari 5 kantor cabang dan 17 kantor cabang pembantu yang tersebar di kota-kota besar lainnya di Sumatera Utara, sedangkan di Medan sendiri terdapat 1 kantor cabang dan 12 kantor cabang pembantu, bisa dilihat tabel di bawah ini :

\begin{tabular}{|l|l|l|}
\hline No & Nama Cabang & $\begin{array}{l}\text { Cakupan Daerah } \\
\text { dan Potensi }\end{array}$ \\
\hline 1 & $\begin{array}{l}\text { Kantor Cabang } \\
\text { Syariah Medan }\end{array}$ & $\begin{array}{l}\text { Terletak di pusat kota Medan } \\
\text { Berdekatan dengan pusat pasar } \\
\text { Berdekatan dengan Istana Maimun dan Mesjid Raya Medan } \\
\text { Berdekatan dengan Lapangan Merdeka Medan } \\
\text { Daerah-daerah tersebut banyak terdapat usaha-usaha }\end{array}$ \\
\hline 2 & $\begin{array}{l}\text { Kantor Capem } \\
\text { Syariah Stabat }\end{array}$ & $\begin{array}{l}\text { Terletak di pusat kota Stabat } \\
\text { Terdapat banyak swalayan/mini market } \\
\text { Dengan dengan rumah makan dan restaurant }\end{array}$ \\
\hline 3 & $\begin{array}{l}\text { Kantor Capem } \\
\text { Syariah Multat- } \\
\text { uli }\end{array}$ & $\begin{array}{l}\text { Terletak di tengah kota Medan } \\
\text { Berdekatan dengan Masjid Agung } \\
\text { Berdekatan dengan rumah Dinas Walikota } \\
\text { Berdekatan dengan komplek perumahan Multatuli } \\
\text { Berdekatan dengan tempat hiburan dan usaha yang ada di } \\
\text { komplek Multatuli }\end{array}$ \\
\hline 4 & $\begin{array}{l}\text { Kantor Capem } \\
\text { Syariah Karya }\end{array}$ & $\begin{array}{l}\text { Berdekatan dengan komplek perumahan Griya } \\
\text { Berdekatan dengan kantor-kantor pemerintah } \\
\text { Berdekatan dengan asrama Rindam Gaperta } \\
\text { Banyak usaha-usaha kuliner }\end{array}$ \\
\hline
\end{tabular}




\begin{tabular}{|c|c|c|}
\hline 5 & $\begin{array}{l}\text { Kantor Capem } \\
\text { Syariah HM. Joni }\end{array}$ & $\begin{array}{l}\text { Berdekatan dengan daerah kampus } \\
\text { Banyak usaha-usaha kuliner } \\
\text { Berdekatan dengan minimarket } \\
\text { Berdekatan dengan pasar sukaramai }\end{array}$ \\
\hline 6 & $\begin{array}{l}\text { Kantor Capem } \\
\text { Syariah Jamin } \\
\text { Ginting }\end{array}$ & $\begin{array}{l}\text { Berdekatan dengan daerah kampus } \\
\text { Banyak usaha-usaha kuliner } \\
\text { Berdekatan dengan minimarket }\end{array}$ \\
\hline 7 & $\begin{array}{l}\text { Kantor Capem } \\
\text { Syariah Binjai }\end{array}$ & $\begin{array}{l}\text { Berdekatan dengan stasiun kereta } \\
\text { Banyak usaha-usaha kuliner } \\
\text { Berdekatan dengan minimarket }\end{array}$ \\
\hline 8 & $\begin{array}{l}\text { Kantor Capem } \\
\text { Syariah Kota } \\
\text { Baru Marelan }\end{array}$ & $\begin{array}{l}\text { Terletak di lingkungan pengusaha-pengusaha mikro } \\
\text { Berdekatan dengan pusat pasar } \\
\text { Terdapat banyak swalayan/mini market } \\
\text { Berdekatan dengan rumah makan dan restaurant }\end{array}$ \\
\hline 9 & $\begin{array}{l}\text { Kantor Capem } \\
\text { Syariah HM. } \\
\text { Yamin }\end{array}$ & $\begin{array}{l}\text { Berdekatan dengan daerah kampus } \\
\text { Banyak usaha-usaha kuliner } \\
\text { Berdekatan dengan minimarket }\end{array}$ \\
\hline 10 & $\begin{array}{l}\text { Kantor Capem } \\
\text { Syariah Marelan } \\
\text { Raya }\end{array}$ & $\begin{array}{l}\text { Terletak di lingkungan pengusaha-pengusaha mikro } \\
\text { Berdekatan dengan pusat pasar } \\
\text { Terdapat banyak swalayan/mini market } \\
\text { Berdekatan dengan rumah sakit } \\
\text { Berdekatan dengan daerah kampus }\end{array}$ \\
\hline 11 & $\begin{array}{l}\text { Kantor Capem } \\
\text { Syariah Ham- } \\
\text { paran Perak }\end{array}$ & $\begin{array}{l}\text { Dikelilingi dengan pengusaha-pengusaha mikro } \\
\text { Berdekatan dengan minimarket } \\
\text { Berdekatan dengan sekolah-sekolah dan instansi lainnya }\end{array}$ \\
\hline 12 & $\begin{array}{l}\text { Kantor Capem } \\
\text { Syariah Kayu } \\
\text { Besar }\end{array}$ & $\begin{array}{l}\text { Berada di daerah pusat Tanjung Morawa } \\
\text { Dikelilingi dengan pengusaha-pengusaha mikro } \\
\text { Berdekatan dengan rumah sakit } \\
\text { Berdekatan juga dengan kampus }\end{array}$ \\
\hline
\end{tabular}

Sumber: Data hasil dari penelitian lapangan

Dari tabel di atas, pembukaan masing-masing kantor cabang Bank Sumut Syariah khususnya cabang Medan dengan maksud agar mudah dijangkau dan antara kedua belah pihak (nasabah dan bank) saling menguntungkan. Serta memancing calon anggota yang kemudian menjadi anggota untuk terus berinteraksi dan melakukan transaksi dengan Bank Sumut Syariah dalam jangka panjang. 


\section{Aspek Pembinaan Masyarakat (Edukasi Perbankan)}

Agar masyarakat dapat memahami pengetahuan tentang jasa dan produk-produk serta pengelolaan sumber pendapatan yang baik, minimnya akses terhadap informasi maupun layanan keuangan dan kurangnya pengetahuan tersebut, membatasi kemampuan individu untuk mengelola panghasilan, memilih jasa dan produk keuangan, maka Bank Sumut Syariah melakukan edukasi pengenalan produk. Keadaan ini memperkuat perlunya edukasi keuangan diberikan kepada masyarakat kelompok bawah untuk meningkatkan pengetahuan mengenai layanan keuangan, dengan berupa kunjungan-kunjungan dan pelatihan.Pengetahuan ini penting agar anggota merasa lebih aman berinteraksi dengan lembaga keuangan. Dengan adanya edukasi tersebut mereka diajak dan diarahkan kepada bagaimana menggunakan uang secara rasional. Dengan adanya sistem informasi yang baik pada anggota maka akan dapat ditingkatkan mutu pengelolaan anggota. Selain edukasi, meningkatkan awareness perbankan juga penting terhadap masyarakat miskin yang produktif, kemudian membuat ketentuan yang mendukung dan menghilangkan ketentuan yang menghambat terhadap masyarakat. Dalam hal ini petugas perbankan juga dapat sekaligus memonitoring tingkat kemajuan usaha pedagang yang nantinya dapat menentukan top-upatau tidak si pedagang.

\section{PENUTUP}

Dari paparan dalam bab-bab sebelumnya, penulis dapat menyimpulkan bahwa:

1. Financial Inclusion pada dasarnya adalah membuka seluasnya akses terhadap jasa keuangan bagi masyarakat khususnya masyarakat golongan bawah sebagai golongan unbank atau juga unbankable.Financial Inclusion merupakan representatif dari prinsip-prinsip ekonomi Islam, dimana business finance tidak hanya bersifat transaksional untuk mencari profit semata. Akan tetapi business finance haruslah bersifat empowerment, untuk memperbaiki taraf hidup masyarakat. Gagasan tentang revitalisasi Financial Inclusion bukan tanpa alasan, sebab Financial Inclusion bisa memberdayakan masyarakat yang selama ini tidak pernah terjamah oleh sistem dan teknologi perbankan.

2. Bank Sumut Syariah mempunyai peran signifikan dalam pengembangan ekonomi masyarakat melalui berbagai pembiayaan mikronya yaitu Pembiayaan Sumut Sejahtera. Hal ini tidak terlepas dari kemudahannya diakses oleh masyarakat. Fasilitas pembiayaan ini memiliki tujuan mulia diberikan kepada masyarakat pra-sejahtera yang memiliki usaha mikro untuk meningkatkan peran masyarakat dalam menopang ekonomi keluarga dengan sistem kelompok guna memperbaiki taraf hidup keluarga pra-sejahtera atau berpenghasilan rendah menuju ke taraf se- 
jahtera yang lebih baik, membina pengusaha mikro yang memiliki kelayakan usaha tetapi belum bankable sehingga menjadi layak menjadi nasabah bank, serta meningkatkan taraf hidup rakyat dan membantu program Pemerintah dalam rangka pengentasan kemiskinan.

3. Penerapan Financial Inclusion pada Pembiayaan Sumut Sejahtera yang ada di Bank Sumut Syariah sudah sangat jelas manfaatnya dalammendorong pertumbuhan ekonomi yang bersumber daya manusia dengan menghindari riba dan menetapkan bagi hasil dalam menegakkan kemashlahatan ummat. Hal ini masuk kedalam prinsip dasar ekonomi Islam yaitu maqashid al-Syariah, bagi Financial Inclusion teori maqashid asy-syari'ah adalah salah satu usaha logis yang wajib diterapkan sebagai konsekuensi dari pemahaman ekonomi yang bertkeadilan di satu sisi dan berketuhanan di sisi lain. Selain itu, kemudian akan dipahami kemaslahatan sebagai kebutuhan manusia termasuk juga dikaitkan dengan lapangan ekonomi akan mengikuti teori-teori ekonomi yang sesuai dengan pencapaian visi dan misi Islam.

4. Jadikan Financial Inclusion hari ini bukanlah merupakan pilihan, tetapi menjadi sebuah keharusan dan perbankan merupakan pendorong utama untuk implementasi Financial Inclusion. Partisipasi lembaga keuangan dalam pengembangan Financial Inclusion secara tepat adalah dengan mengembangkan program yang tidak hanya mengandalkan usaha pada penghimpunan dana tabungan atau pembiayaan, tetapi harus ikut aktif mengentaskan kemikinan melalui pembangunan keluarga dengan akses pembiayaan yang lebih luas bagi keluarga atau masyarakat miskin. 


\section{DAFTAR PUSTAKA}

Abdul Rasyid, http://business-law.binus.ac.id/2016/07/30/tugas-dan-wewenang-antarabank-indonesia-dengan-otoritas-jasa-keuangan-tehadap-sektor-keuangan-bagian1-dari-2-tulisan/ diakses Tanggal 17 Januari 2016

Ahmad, M. Amrullah, Strategi Dakwah di Tengah Era Reformasi Menuju Indonesia Baru Dalam Memasuki Abad 21, (Bandung: 1999).

Evalisa Siregar, http://sumut.antaranews.com/berita/156790/pemprov-sumut-bentuktim-percepatan-akses-keuangan-daerah. diakses Tanggal 18 Januari 2017

Farhan Maulani, Pengertian Financial Inclusionhttp://handuk-qu.blogspot.com/2013/12/ pengertian-financial-inclusion.html=, diakses 2 Juni 2016

Halim Alamsyah, "Pentingnya Keuangan Inklusif dalam Meningkatkan Akses Masyarakat dan UMKM terhadap Fasilitas Jasa Keuangan Syariah", diakses Tanggal 1 Juni 2016

Ife, Jim, Community Development, Australia: Penerbit Longman, 2005

Kamus Besar Bahasa Indonesia, Jakarta: Balai Pustaka, 2003.

Kementrian Keuangan (2013) Strategi Nasional di Keuangan Inklusif, www.fiskal. depkeu.go.id, diakses Tanggal 1 Juni 2016

Melisa Salim, et.al, Analisis Implementasi Program Financial Inclusion Di Wilayah Jakarta Barat dan Jakarta Selatan (Studi pada Pedagang Golongan Mikro, Instansi Perbankan, Otoritas Jasa Keuangan dan Bank Indonesia), [Skripsi], Universitas Bina Nusantara, 2014.

Novia Nengsih, Peran Perbankan Syariah dalam Mengimplementasikan Keuangan Inklusif di Indonesia, Etikonomi, Vol 14 No 2 (Oktober 2015).

Pradjosto Hardojo, Antonio, dkk, Mendahulukan Si Miskin, (Yogyakarta:LKiS Pelangi Aksara, 2008).

Rukminto, Isbandi, Pemikiran-pemikiran dalam Pembangunan Kesejahteraan Sosial, (Jakarta: Lembaga Penerbit Fakultas Eokonomi Universitas Indonesia, 2002), hal. 162.

Serraden Michael, Asset and The Poor. A New American Welfare Policy, yang kemudian diterjemahkan oleh Sirajuddin Abbas et. Al. dengan judul Aset Untuk Orang Miskin:Perssepektif Baru Usaha Pengentasan Kemiskinan, Jakarta: Raja Grafindo Persada, 2006.

Sumodiningrat, Gunawan, Kepemimpinan dan Pemberdayaan Ekonomi Rakyat, naskah Pidato Pengukuhan Jabatan Guru Besar pada Fakultas Ekonomi Universitas Gadjah Mada 17 Maret 2001, Yogyakarta: UGM, 2001. 
Triana Fitriastuti, et.al, Implementai Keuangan Inklusif Bagi Masyarakat Perbatasan (Studi Kasus Pada Kutai Timur, Kabupaten Kutai Kartanegara dan Kota Samarinda Kalimantan Timur, Indonesia), (2015).

Yohanes, Mardimin, Kritis Proses Pembangunan di Indonesia. (Yogyakarta.: Penerbit Kanisius, 1996).

www.banksumut.com 